\title{
Clinical Significance of Smoking Cessation in Subjects With Cancer: A 30-Year Review
}

\author{
Angeliki N Florou MD, Ioannis CH Gkiozos MD, Sophia K Tsagouli MD, \\ Kyriakos N Souliotis PhD, and Konstantinos N Syrigos MD PhD
}

\author{
Introduction \\ Methods \\ Results \\ Effect of Continued Smoking on Survival, Mortality, and Disease \\ Progression in Patients With Cancer \\ Impact of Smoking and Smoking Cessation on Cancer Treatment \\ Effectiveness \\ Clinical Importance of Smoking Cessation on Quality of Life, Pain, and \\ Performance Status
}

Discussion

BACKGROUND: Despite the established causal relationship between tobacco smoking and cancer, many cancer patients continue to smoke after diagnosis. This partly reflects ignorance of the beneficial effects of smoking cessation, even after diagnosis. The aim of this study was to demonstrate the effects of continuing or quitting smoking in patients with diagnosed cancer. METHODS: The study was based on a review of medical databases (PubMed Central, MEDLINE, Cochrane Library) in the last $30 \mathrm{y}$. All articles included in the present analysis were in English. RESULTS: In subjects with early-stage lung cancer, continued smoking after diagnosis is associated with an increased risk of all-cause mortality and decreased survival. Research has demonstrated significant differences in actuarial overall survival favoring the non-smoking group among subjects with lung cancer. In subjects with oral cancer, smoking cessation or reduction leads to a significant reduction in mortality. There is also evidence that tobacco smoking aggravates and prolongs radiotherapyinduced complications. Of particular importance is evidence that continued smoking is associated with adverse effects during anti-cancer treatment. Smoking promotes tumor progression and increases resistance to chemotherapy due to nicotine-induced resistance to apoptosis by modulating mitochondrial signaling. Continued smoking is also related to inferior outcomes of treatment with novel targeted therapies such as erlotinib. Smoking in subjects with gastric and lung cancer is also associated with an increased risk of developing second primary tumors. Quitting smoking after lung cancer diagnosis is associated with a better performance status, whereas persistent smokers have worse overall quality of life. Subjects who continue to smoke despite being diagnosed with cancer report more severe pain than subjects who have never smoked and greater pain-related functional impairment. CONCLUSIONS: Continued smoking after cancer diagnosis is related to reduced treatment efficacy and reduced survival, increased risk for second primary malignancies, and deterioration of quality of life. Key words: lung cancer; smoking; smoking cessation; quality of life [Respir Care 2014;59(12):1924-1936. @ 2014 Daedalus Enterprises] 


\section{Smoking Cessation in Subjects With Cancer}

\section{Introduction}

Tobacco smoking has been clearly linked to the development of lung cancer and also related to increased risk of several other cancers, notably oral, laryngeal, pharyngeal, esophageal, stomach, liver, pancreatic, kidney, bladder, uterine cervix cancer and myeloid leukemia. ${ }^{1}$ Smoking accounts for $30 \%$ of all cancer deaths and $87 \%$ of lung cancer deaths. ${ }^{2}$

Research indicates that after cancer diagnosis, motivation and intention for smoking cessation are greatly increased, particularly in patients with cancer types strongly related to smoking, such as head and neck cancer and lung cancer. However, up to one third to one half of cancer patients continue to smoke after diagnosis or relapse after successful initial attempts to quit, depending on tumor site and duration of follow-up. ${ }^{3}$ Smoking rates are high even in patients with cancers most strongly related to smoking. Twenty-three to $35 \%$ of subjects with head and neck cancer and $13-20 \%$ of patients with lung cancer continue to smoke after diagnosis. ${ }^{4}$

Although the importance of smoking cessation in the primary prevention of cancer is well recognized, its significance for individuals diagnosed with, treated for, and surviving cancer is often overlooked. ${ }^{2,3}$

There is a growing body of evidence indicating that continued smoking after the diagnosis of cancer has substantial adverse effects on cancer patients. The aim of this review was to investigate and report the benefits of smoking cessation and the negative effects of continued smoking on survival measures, treatment effectiveness, risk of a second primary malignancy, and quality of life. Such knowledge may increase motivation to stop smoking and help those who quit to remain abstinent.

\section{Methods}

In this study, we conducted a comprehensive review of literature discussing the benefits of smoking cessation and

Dr Florou is affiliated with the Pulmonary and Critical Care Department, Evgenidion Hospital, and Drs Gkiozos, Tsagouli and Syrigos are affiliated with the Oncology Unit of the 3rd Internal Medicine Clinic, Sotiria General Hospital, Athens Medical School, Greece. Dr Souliotis is affiliated with the Faculty of Social Sciences, University of Peloponnese, Corinth, Greece.

The authors have disclosed no conflicts of interest.

Correspondence: Konstantinos Syrigos MD PhD, Sotiria General Hospital, Athens School of Medicine, 152 Mesogeion Avenue, Athens 11527, Greece. E-mail: ksyrigos@med.uoa.gr.

DOI: $10.4187 /$ respcare.02559 the negative effects of continued smoking after cancer diagnosis. A systematic search was carried out in bibliographic databases (PubMed Central, MEDLINE, Cochrane Library). We searched for randomized controlled trials and observational longitudinal studies in cancer subjects related to smoking habits. We identified papers published until July 2013. We also performed a cited-reference search by reviewing references in the retrieved articles. We followed the main steps for reporting systematic reviews according to Preferred Reporting Items for Systematic Reviews and Meta-Analyses guidelines as proposed by Wieseler and McGauran. 5

We conducted separate searches using combinations of the following terms: tobacco smoking and cancer, smoking cessation benefits and cancer, cancer survival and smoking, smoking and tumor progression, and cancer and quality of life.

We included studies with the following characteristics: (1) adult subjects with cancer regardless of the type or site of the malignancy; (2) studies with clear reference to smoking status, such as never-smokers, ex-smokers, and current smokers (some studies further classified ex-smokers into distant ex-smokers and recent ex-smokers, although the criteria for this designation were not homogeneously defined, or divided them into several groups based on the duration of abstinence); (3) studies published over the last $30 \mathrm{y}$; and (4) studies evaluating the impact of smoking status after the diagnosis of malignancy on survival and the course of disease in cancer subjects. We included studies written only in English and excluded studies with no access to full-text manuscripts and studies referring to the causal relationship between tobacco smoking and several types of cancer.

The original question of this review is general in that the effects of smoking habits after the diagnosis of cancer cannot be measured by a single parameter or outcome. For this reason, smoking habits (continuing or quitting) after the diagnosis of the malignancy were evaluated in relation to 4 different issues: survival, impact on treatment effectiveness, risk for second primary tumors, and quality of life.

\section{Results}

A large volume of studies were identified from the initial research: 8,332 papers from the last decade and 11,755 studies regardless of the date matched at least one of the search terms. After this initial screening, any paper that did not contain 2 or more of the search terms or did not fulfill all the aforementioned inclusion criteria was excluded from further evaluation. Two independent reviewers read 380 abstracts and 162 full-text papers. A total of 20 studies were finally included in this review. 


\section{Smoking Cessation in Subjects With Cancer}

Table 1. Studies Evaluating the Effects of Smoking on Survival, Mortality, and Disease Progression

\begin{tabular}{|c|c|c|c|c|c|c|}
\hline Reference & $\begin{array}{c}\text { Type of } \\
\text { Cancer/Stage }\end{array}$ & $\begin{array}{c}\text { Subjects } \\
(n)\end{array}$ & $\begin{array}{l}\text { Study } \\
\text { Design }\end{array}$ & $\begin{array}{l}\text { Assessment of } \\
\text { Smoking Status }\end{array}$ & Outcomes & $\begin{array}{l}\text { Main Results in Relation to } \\
\text { Smoking Status }\end{array}$ \\
\hline Videtic et al ${ }^{8}$ & $\begin{array}{l}\text { Small-cell lung cancer } \\
\text { (limited stage) }\end{array}$ & 215 & Retrospective & $\begin{array}{l}\text { Smokers, non-smokers } \\
\text { (at the initiation of } \\
\text { treatment) }\end{array}$ & $\begin{array}{l}\text { OS, DFS, toxicity-related } \\
\text { treatment interruptions }\end{array}$ & $\begin{array}{l}\text { Increased OS in non-smokers } \\
\text { No improvement in DFS }\end{array}$ \\
\hline Zhou et $\mathrm{al}^{9}$ & $\begin{array}{l}\text { Non-small-cell lung } \\
\text { cancer (stages IA and } \\
\text { IIB) }\end{array}$ & 543 & Prospective & $\begin{array}{l}\text { Never-smokers, ex- } \\
\text { smokers, current } \\
\text { smokers }\end{array}$ & OS, RFS & $\begin{array}{l}\text { Increased OS, RFS in } \\
\text { women }\end{array}$ \\
\hline Chen et al ${ }^{10}$ & $\begin{array}{l}\text { Small-cell lung cancer } \\
\text { (limited stage) }\end{array}$ & 284 & Prospective & $\begin{array}{l}\text { Smokers, ex-smokers at } \\
\text { or after diagnosis }\end{array}$ & OS, RFS, DFS & $\begin{array}{l}\text { Increased OS, RFS, and DFS } \\
\text { in ex-smokers compared } \\
\text { with smokers }\end{array}$ \\
\hline Jerjes et al ${ }^{11}$ & $\begin{array}{l}\text { Squamous cell carcinoma } \\
\text { of oral cavity and } \\
\text { oropharyngeal region }\end{array}$ & 67 & Prospective & $\begin{array}{l}\text { Non-smokers, ex-smokers, } \\
\text { chronic smokers } \\
\text { (5 categories) }\end{array}$ & Survival & $\begin{array}{l}\text { Increased OS (reduction in } \\
\text { mortality) in ex-smokers }\end{array}$ \\
\hline \multirow[t]{3}{*}{ Rink et al ${ }^{12}$} & $\begin{array}{l}\text { Bladder cancer (non- } \\
\text { muscle-invasive) }\end{array}$ & 2,043 & Prospective & $\begin{array}{l}\text { Current smokers, } \\
\text { ex-smokers, } \\
\text { never-smokers }\end{array}$ & $\begin{array}{l}\text { OS, disease progression, } \\
\text { disease recurrence }\end{array}$ & $\begin{array}{l}\text { Association of smoking with } \\
\text { disease progression }\end{array}$ \\
\hline & & & & $\begin{array}{l}\text { Lifetime cumulative } \\
\text { exposure }\end{array}$ & & $\begin{array}{l}\text { No association with disease } \\
\text { recurrence }\end{array}$ \\
\hline & & & & & & $\begin{array}{l}\text { Lower risk for recurrence in } \\
\text { long-time ex-smokers } \\
(>10 \mathrm{y})\end{array}$ \\
\hline \multirow[t]{2}{*}{ Rink et al ${ }^{13}$} & $\begin{array}{l}\text { Bladder cancer } \\
\text { (recurrent) }\end{array}$ & 390 & Prospective & $\begin{array}{l}\text { Current smokers, } \\
\text { ex-smokers, } \\
\text { never-smokers }\end{array}$ & $\begin{array}{l}\text { OS, disease progression, } \\
\text { disease recurrence }\end{array}$ & $\begin{array}{l}\text { No difference in disease } \\
\text { progression and recurrence } \\
\text { between groups }\end{array}$ \\
\hline & & & & $\begin{array}{l}\text { Smoking duration years } \\
\text { since cessation }\end{array}$ & & $\begin{array}{l}\text { Cumulative smoking } \\
\text { exposure as an } \\
\text { independent risk factor for } \\
\text { recurrence }\end{array}$ \\
\hline \multirow[t]{2}{*}{ Braithwaite et al ${ }^{14}$} & $\begin{array}{l}\text { Breast cancer (stages I, } \\
\text { II, and IIIA) }\end{array}$ & 2,258 & Prospective & $\begin{array}{l}\text { Never-smokers, current } \\
\text { smokers and ex- } \\
\text { smokers }\end{array}$ & $\begin{array}{l}\text { Mortality (disease-specific, } \\
\text { all and other causes) }\end{array}$ & $\begin{array}{l}\text { Increased risk of mortality } \\
\text { (breast cancer-specific, all } \\
\text { and other causes) in } \\
\text { current smokers }\end{array}$ \\
\hline & & & & & & $\begin{array}{l}\text { Increased risk of all-cause } \\
\text { mortality in ex-smokers }\end{array}$ \\
\hline Saito-Nakaya et al ${ }^{15}$ & $\begin{array}{l}\text { Non-small-cell lung } \\
\text { cancer after curative } \\
\text { surgery }\end{array}$ & 238 & Prospective & $\begin{array}{l}\text { Current smokers, } \\
\text { ex-smokers, } \\
\text { never-smokers }\end{array}$ & OS & $\begin{array}{l}\text { Increased overall survival for } \\
\text { never-smokers compared } \\
\text { with current and ex- } \\
\text { smokers }\end{array}$ \\
\hline \multicolumn{7}{|c|}{$\begin{array}{l}\text { DFS }=\text { disease-free survival } \\
\text { RFS }=\text { recurrence-free survival }\end{array}$} \\
\hline
\end{tabular}

\section{Effect of Continued Smoking on Survival, Mortality, and Disease Progression in Subjects With Cancer}

The impact of continued smoking during treatment on outcome in limited-stage small-cell lung cancer was investigated in the 1980s in 2 reports. ${ }^{6,7}$ The results of those reports were conflicting. In the study of Johnston-Early et al, ${ }^{6}$ subjects who continued to smoke had worse survival rates, whereas in the study of Bergman and Sörenson, ${ }^{7}$ there was no difference in survival between those who did and did not smoke while receiving treatment. However, these reports had some serious limitations: the study populations included a mixture of limited and extensive-stage subjects, and in neither report did the treatment use contemporary standards of combined chemotherapy and radiotherapy.

In this study, 8 papers were systematically reviewed (Table 1). Four of them included lung cancer subjects with primary end points of overall survival, disease-free sur- vival, and/or recurrence-free survival; one was performed in subjects with squamous cell carcinoma of the oral cavity and oropharyngeal region with survival as the main outcome; 2 were performed in subjects with invasive bladder cancer with disease progression and recurrence as the primary outcomes; and one involved women with breast cancer with a primary end point of mortality. These studies were not randomized.

Videtic et $\mathrm{al}^{8}$ performed a retrospective review of subjects with limited-stage small-cell lung cancer treated with concurrent chemoradiotherapy to determine whether smoking during treatment affects survival and toxicity. A total of 215 subjects with limited-stage small-cell lung cancer were evaluated. There was a significant difference in actuarial overall survival favoring the non-smoking cohort. Statistical significance was not demonstrated for diseasefree survival. The poorer survival among smokers was not attributable to an excess number of deaths from non-cancer comorbidities. 
The association between smoking status and toxicityrelated treatment interruptions was also analyzed. Survival outcomes were least favorable in subjects who continued to smoke and experienced treatment breaks and most favorable in non-smokers without treatment breaks. Better survival outcomes were observed in non-smoking subjects who received prophylactic cranial irradiation and had no radiotherapy breaks. Median survival was 23 months, and the 2-y and 5-y survival rates were 50\% and $26.8 \%$, respectively. Continued smoking had the greatest negative impact on survival among several possible prognostic factors.

In the study of Zhou et al, ${ }^{9} 543$ subjects with early-stage (stages IA and IIB) non-small-cell lung cancer were prospectively followed up after surgical resection to evaluate whether smoking cessation before diagnosis affects survival. The end points in this study were overall survival and recurrence-free survival. Smoking cessation was associated with a non-statistically significantly better overall survival $(P=.09)$ in the entire study population. The significantly beneficial effect of smoking cessation on recurrence-free survival or overall survival was observed in women, but not in men. The authors also demonstrated that the length of survival was positively correlated with the duration of smoking abstinence. Factors related to statistically significant worse overall survival or recurrencefree survival were heavier smoking, older age, male gender, more advanced stage, and squamous cell type.

In their prospective cohort study, Saito-Nakaya et al ${ }^{15}$ investigated the association of marital status and social support to survival after curative surgery in non-small-cell lung cancer subjects. In analysis of survival, smoking status before surgery (ex-smokers and current smokers) and after surgery (ex-smokers, smokers who quit, and smokers who continued) were found to be significantly associated with lung cancer survival, along with sex, age, occasion of cancer diagnosis (follow-up for other diseases), pathological stage, and serum albumin levels.

More recently, in 2010, Chen et al ${ }^{10}$ conducted a prospective cohort study of limited-stage small-cell lung cancer subjects investigating the possible independent impact of various factors (age, sex, smoking status at time of diagnosis, smoking cessation, performance status, treatment regimens) on survival and determining the magnitude of the impact. Two-hundred eighty-four subjects with limited-stage small-cell lung cancer were included. Subjects were classified as never-smokers, ex-smokers, and current smokers and the duration of smoking abstinence at the time of diagnosis and during follow-up was also factored. Neither smoking status at the time of limited-stage small-cell lung cancer diagnosis (ex-smokers or current smokers) nor intensity (pack-years smoked) had a significant impact on limited-stage small-cell lung cancer survival. However, compared with smokers (who never quit smoking), subjects who quit at or after diagnosis had their risk of death reduced by $45 \%$ after adjustment for other variables.

Jerjes et al ${ }^{11}$ investigated the effect of reduction/cessation of tobacco and alcohol, which are the most predominant risk factors for cancer of the oral cavity and oropharyngeal region, on mortality in oral cancer subjects. In this study, 67 subjects with squamous cell carcinoma undergoing surgical resection for their malignancy were followed up for a minimum period of $5 \mathrm{y}$. The 3 -year survival rate in this cohort was $46.8 \%$, and the 5-year survival rate was $40.4 \%$. Reduction or cessation of smoking led to a significant reduction in mortality at $3 \mathrm{y}(P<.001)$ and $5 \mathrm{y}$ $(P<.001)$.

Recent publications have also focused on the role of smoking cessation in patients with primary non-muscle invasive bladder cancer. In the study by Rink et al, ${ }^{12} 2,043$ subjects with primary non-muscle invasive bladder cancer were followed up to analyze the effects of smoking status, cumulative exposure, and time from smoking cessation on this specific group. Smoking status was significantly associated with cumulative incidence of disease recurrence $(P=.04)$ and progression $(P<.001)$. Current smokers had the highest cumulative incidence for both end points. Smoking status was not associated with overall survival $(P=.66)$. In ever-smokers, cumulative smoking exposure was significantly associated with disease recurrence $(P<.001)$, progression $(P<.001)$, and overall survival $(P<.001)$. Long-term heavy smokers had the worst outcomes. In multivariate analyses, smoking status was not significantly associated with disease recurrence $(P=.12)$, but it was associated with disease progression $(P=.003)$. Current smokers had a 2.09 times $(95 \%$ confidence interval [CI], 1.29-3.39) increased risk for disease progression as compared with never-smokers. The risk of disease progression did not differ between never-smokers and exsmokers. Compared with current smokers, subjects who quit smoking $\geq 10$ y before surgery (transurethral bladder resection) had a 0.66 times lower risk for disease progression (95\% CI, 0.52-0.84) and a 0.42 times lower risk for disease progression.

The impact of smoking on disease state in subjects with recurrent non-muscle invasive bladder cancer has also been evaluated by Rink et al. ${ }^{13}$ In this study, a total of 390 subjects with recurrent non-muscle invasive bladder cancer undergoing transurethral bladder resection were evaluated. The authors did not find differences in disease recurrence and progression among never-smokers, exsmokers, and current smokers. Subjects with long-term heavy cumulative smoking exposure were at significantly increased risk for disease recurrence and progression compared to subjects with short-term moderate or light exposure. In multivariate analysis, increasing cumulative smoking exposure was significantly associated with disease 
recurrence and progression in ever-smokers $(P \leq .003)$. Compared with distant ex-smokers, recent ex-smokers exhibited a higher disease recurrence rate $(P<.001)$, similar to that of current smokers. On multivariate Cox regression analysis, adjusted for clinicopathological features, distant ex-smokers were at significantly decreased risk for disease recurrence compared with current smokers (hazard ratio $0.40,95 \%$ CI, $0.2-0.7 ; P<.001)$. In terms of overall survival, no statistically significant differences were demonstrated $(P>.05)$, although current smokers had worse survival rates than ex-smokers.

The association between smoking and survival following breast cancer diagnosis was evaluated in the study of Braithwaite et al. ${ }^{14}$ In this prospective observational study, 2,270 women who had completed breast cancer treatment and were free of recurrence were followed up for a median of $12 \mathrm{y}$. The end points of the study were mortality from breast cancer, other causes, and all causes. Smoking status data were available for 2,258 women. Differences were observed in all-cause and other-cause mortalities in relation to smoking status, and, to a lesser extent, in breast cancer deaths. Current smokers showed a significantly higher risk of breast-specific, all-cause, and competingcause mortalities and a 2-fold increase in the risk of breast cancer death compared with never-smokers. Ex-smokers showed an increased risk of all-cause mortality and an 1.35 times increased risk of breast cancer-specific mortality in unadjusted models. The authors also found an increased risk of breast cancer death in premenopausal and postmenopausal women who were current smokers and only in premenopausal ex-smokers. A stronger association was found between current smoking and cancer-specific mortality in women with normal weight (body mass index of $<25 \mathrm{~kg} / \mathrm{m}^{2}$ ) than in women with a body mass index of $>25 \mathrm{~kg} / \mathrm{m}^{2}$.

\section{Impact of Smoking and Smoking Cessation on Cancer Treatment Effectiveness}

\section{Effect of Continued Smoking on Efficacy of Radiation}

Therapy. Cigarette smoking is an important risk factor for the development of head and neck squamous cell cancers. The impact of smoking on the efficacy of radiation therapy in head and neck cancer was studied by Browman et $\mathrm{al}^{16}$ in the early 1990s (Table 2). In this study, 115 subjects with histologically confirmed localized stage III and IV squamous cell carcinoma of the head and neck were recruited for a randomized trial involving treatment with radiation and chemotherapy. The treatment regimen involved delivery of a total dose of 6,600 rad in 33 fractions over a period of 6.5 weeks. During the first and third weeks of treatment, subjects were assigned to receive either fluorouracil or placebo. Smoking history, smoking status, and history of alcohol consumption were recorded.
Subjects who reported smoking at least one cigarette during the 6.5 weeks of radiation therapy were classified as smokers, and those who denied smoking during treatment were classified as abstainers. Adverse effects were assessed weekly with several scales and by monitoring body weight, serum albumin levels, and performance status. The response of the tumor was determined 13 weeks after the completion of radiation therapy. Subjects were classified as showing complete response or no response.

During the treatment period, $54 \%$ of the subjects did not smoke, whereas $46 \%$ continued smoking. ${ }^{16}$ Among subjects who continued to smoke during radiation therapy, only $45 \%$ had a complete response compared with $74 \%$ who abstained from smoking $(P=.008)$. The 2-year survival rate was $66 \%$ in the non-smoking group compared with $39 \%$ in the smoking group $(P=.005)$.

The researchers also calculated the difference in survival rate between recent quitters (smokers who had quit $<12$ weeks before the diagnosis) and long-time quitters (those who had quit $>1 \mathrm{y}$ before the diagnosis). ${ }^{16}$ The difference in survival was statistically significant $(P=.005)$ and was related to the length of time between quitting and treatment. Compared with smokers, the risk of mortality 18 months after treatment was 0.4 for the entire group of abstainers, 0.3 for subjects who had not smoked for $>1 \mathrm{y}$ before the diagnosis, and 0.6 for subjects who had quit smoking $<12$ weeks before the diagnosis. The risk of mortality was not significantly different in the 2 subgroups of non-smokers $(P=.31)$.

The effect of smoking could not be explained by differences in subject and tumor baseline characteristics. Differences in the frequency of treatment (radiation or chemotherapy) interruption were observed, but the authors believe that it is unlikely that the number of these events accounts for the magnitude of difference in treatment outcomes. ${ }^{16}$

The regression model for survival included age, tumor stage, tumor site, treatment (fluorouracil or placebo), and smoking status during treatment. Smoking during radiation therapy emerged as the only significant variable independently associated with survival $(P=.002)$, with a relative risk of 2.5 in favor of those who did not smoke during treatment. The authors also examined all potential interactions of the variables contained in the model. No interaction terms were significant, and with the introduction of the interaction terms, smoking remained an independent predictor of survival with a relative risk of 2.3 in favor of those who did not smoke during radiotherapy.

In conclusion, among subjects with locally advanced stage III or IV squamous cell carcinoma of the head and neck treated with radiation therapy, those who continued to smoke during therapy had a lower rate of response and survival than those who abstained from smoking during treatment. ${ }^{16}$ 


\section{Smoking Cessation in Subjects With Cancer}

Table 2. Studies Evaluating the Impact of Smoking on Cancer Treatment, Effectiveness, and Second Primary Tumors

\begin{tabular}{|c|c|c|c|c|c|c|}
\hline Reference & $\begin{array}{c}\text { Type of } \\
\text { Cancer/Stage }\end{array}$ & $\begin{array}{l}\text { Subjects } \\
\quad(n)\end{array}$ & Study Design & $\begin{array}{l}\text { Assessment of } \\
\text { Smoking Status }\end{array}$ & Outcomes & $\begin{array}{l}\text { Main Results in Relation } \\
\text { to Smoking Status }\end{array}$ \\
\hline \multirow[t]{3}{*}{ Browman et al ${ }^{16}$} & \multirow[t]{3}{*}{$\begin{array}{l}\text { Head and Neck (stages } \\
\text { III and IV) }\end{array}$} & \multirow[t]{3}{*}{115} & \multirow[t]{3}{*}{$\begin{array}{l}\text { Randomized } \\
\text { prospective }\end{array}$} & \multirow{3}{*}{$\begin{array}{l}\text { Smokers or abstainers } \\
\text { during treatment } \\
\text { (chemoradiotherapy) }\end{array}$} & 2-y survival & $\begin{array}{l}\text { Increased 2-y survival in } \\
\text { abstainers }\end{array}$ \\
\hline & & & & & \multirow[t]{2}{*}{$\begin{array}{l}\text { Response (complete or } \\
\text { none) }\end{array}$} & $\begin{array}{l}\text { Better survival in long- } \\
\text { time ex-smokers }\end{array}$ \\
\hline & & & & & & $\begin{array}{l}\text { Lower complete response } \\
\text { in current smokers }\end{array}$ \\
\hline Clark et al ${ }^{17}$ & $\begin{array}{l}\text { Non-small-cell lung } \\
\text { cancer }\end{array}$ & 311 & Retrospective & $\begin{array}{l}\text { Current smokers, } \\
\text { ex-smokers, } \\
\text { never-smokers }\end{array}$ & OS & $\begin{array}{l}\text { Greatest benefit in survival } \\
\text { from erlotinib in never- } \\
\text { smokers, epidermal } \\
\text { growth factor receptor- } \\
\text { positive }\end{array}$ \\
\hline Shepherd et al ${ }^{18}$ & $\begin{array}{l}\text { Non-small-cell lung } \\
\text { cancer }\end{array}$ & 713 & $\begin{array}{l}\text { Randomized } \\
\text { double- } \\
\text { blind }\end{array}$ & $\begin{array}{l}\text { Current smokers, } \\
\text { never-smoker, } \\
\text { unknown }\end{array}$ & OS, PFS & $\begin{array}{l}\text { Better responsiveness to } \\
\text { erlotinib in never- } \\
\text { smokers }\end{array}$ \\
\hline Johnson et al ${ }^{19}$ & $\begin{array}{l}\text { Non-small-cell lung } \\
\text { cancer }\end{array}$ & 731 & $\begin{array}{r}\text { Randomized } \\
\text { controlled }\end{array}$ & $\begin{array}{l}\text { Never-smokers, } \\
\text { current smokers, } \\
\text { ex-smokers, } \\
\text { unknown }\end{array}$ & $\begin{array}{l}\text { OS (primary), PFS, } \\
\text { quality of life, tumor } \\
\text { response, tumor- } \\
\text { response duration }\end{array}$ & $\begin{array}{l}\text { Better survival in never- } \\
\text { smokers }\end{array}$ \\
\hline Kumar et al ${ }^{20}$ & $\begin{array}{l}\text { Squamous cell carcinoma } \\
\text { of the oropharynx } \\
\text { (stages III and IV) }\end{array}$ & 66 & Prospective & $\begin{array}{l}\text { Never-smokers, } \\
\text { ex-smokers, current } \\
\text { smokers }\end{array}$ & $\begin{array}{l}\text { DSS, OS, response to } \\
\text { therapy }\end{array}$ & $\begin{array}{l}\text { Poorer DSS in current } \\
\text { smokers }\end{array}$ \\
\hline Kinoshita et al ${ }^{21}$ & $\begin{array}{l}\text { Gastric cancer (stages } \\
\text { I-III) }\end{array}$ & 1,614 & Prospective & $\begin{array}{l}\text { Never-smokers, } \\
\text { ex-smokers, current } \\
\text { smokers }\end{array}$ & $\begin{array}{l}\text { Risk for second primary } \\
\text { tumor }\end{array}$ & $\begin{array}{l}\text { Increased risk for } \\
\text { smoking-related cancers }\end{array}$ \\
\hline Tucker et $\mathrm{al}^{22}$ & $\begin{array}{l}\text { Small-cell lung cancer } \\
\text { (limited stage) }\end{array}$ & 611 & Retrospective & $\begin{array}{l}\text { Non-smokers, } \\
\text { ex-smokers, } \\
\text { continued smokers }\end{array}$ & Risk for second cancer & $\begin{array}{l}\text { 3.5-fold increased risk for } \\
\text { any cancer type, } 7 \text {-fold } \\
\text { for smoking-related } \\
\text { cancers }\end{array}$ \\
\hline \multicolumn{7}{|c|}{$\begin{array}{l}\mathrm{OS}=\text { overall survival } \\
\mathrm{PFS}=\text { progression-free survival }\end{array}$} \\
\hline
\end{tabular}

Effect of Smoking Status and Continued Smoking on Cancer Chemotherapy and Epidermal Growth Factor Receptor Tyrosine Kinase Inhibitors. There is growing evidence that continued smoking after cancer diagnosis promotes tumor progression and increases resistance to therapy in patients with lung cancer. ${ }^{8}$ Tumor promoters possess the ability to block apoptosis, an important mechanism in the development and growth of tumors. Many anti-cancer therapeutic agents, including drugs and radiation, kill tumor cells through apoptosis, and therefore, inhibition of apoptosis may promote resistance to cancer therapy. ${ }^{23}$ Recent reports show that nicotine inhibits apoptosis in various cell lines. These observations suggest that nicotine may have the ability not only to promote lung cancer development by activating cell growth pathways, but also to reduce the efficacy of chemotherapeutic agents by stimulating survival pathways. ${ }^{24}$

Epidermal growth factor receptor tyrosine kinase inhibitors constitute a class of novel biologically targeted agents that are widely used in the management of locally advanced or metastatic non-small-cell lung cancer after fail- ure of prior chemotherapy or as first-line treatment in epidermal growth factor receptor-positive patients. Erlotinib is an oral epidermal growth factor receptor inhibitor that is currently approved in second-line and third-line treatment for non-small-cell lung cancer. ${ }^{19,25}$ In clinical trials using erlotinib, subjects were characterized according to their smoking status as never-smokers, ex-smokers, or current smokers. All subgroups of smokers benefited from erlotinib therapy compared with placebo, but the magnitude of benefit varied with smoking status. Median survival in the erlotinib arm was 12.3 months in never-smokers, 5.5 months in ex-smokers, and 6.12 months in current smokers $(P=.006) .{ }^{17-19,25,26}$ These differences have been attributed to several factors, including differences in the natural history and histological type of lung cancer and pharmacokinetics of erlotinib between smokers and never-smokers. The more serious adverse events observed in ex-smokers and never-smokers receiving the erlotinib treatment are suggestive of differences in erlotinib exposure across various smoking status groups. It is now proven that plasma levels of erlotinib are reduced by cigarette smoking. Cur- 
rent smokers show as much as a 2 -fold decrease in erlotinib plasma concentrations compared with ex-smokers or never-smokers. Therefore, erlotinib would be theoretically less effective in smokers due to lower serum levels of the drug. ${ }^{26,27}$ Hughes et al ${ }^{26}$ investigated the hypothesis that the reduction in erlotinib exposure seen in current smokers may be attributed, at least in part, to the induction of cytochrome P enzymes CYP1A1 and CYP1A2 by tobacco smoking. The researchers concluded that the maximum tolerated dose of erlotinib in non-small-cell lung cancer subjects who continued to smoke was $300 \mathrm{mg} / \mathrm{d}$, a finding that contrasts with the previously accepted maximum tolerated dose of $150 \mathrm{mg}$ in unselected patients. The results of this study indicate that exposure and toxicity of erlotinib may be influenced by cigarette smoking. Based on these findings, patients with non-small-cell lung cancer who continue to smoke are strongly advised to quit before starting treatment with erlotinib.

Smoking status has also been analyzed, among other factors such as biomarkers (epidermal growth factor receptor, p53, p16, and $\mathrm{Bcl}-\mathrm{x}_{\mathrm{L}}$ expression and $\mathrm{p} 53$ mutation), sex, and human papilloma virus presence and titer, in relation to its effect on response to therapy and on survival in subjects with advanced squamous cell carcinoma of the oropharynx. ${ }^{20}$ A history of never smoking or former smoking was significantly correlated with higher p16 expression $(P=.01)$ and lower epidermal growth factor receptor $(P=.04)$ and $\mathrm{Bcl}-\mathrm{x}_{\mathrm{L}}(P=.02)$ expression. All subjects with a p53 mutation were ex-smokers or current smokers. After adjusting for smoking status, p53 and $\mathrm{Bcl}-\mathrm{x}_{\mathrm{L}}$ combined and epidermal growth factor receptor alone each held prognostic significance for overall survival and disease-specific survival. Similarly, after analysis was adjusted for smoking status, p16 still held prognostic value for overall survival. In this cohort, epidermal growth factor receptor, HPV16, and p16 each independently predicted survival, and when combined, these markers were associated with survival outcomes. Epidermal growth factor receptor expression was significantly higher in current smokers than in ex-smokers, who in turn had higher epidermal growth factor receptor levels compared with never-smokers. This suggests that smoking may contribute to increased epidermal growth factor receptor expression. Current smokers with high tumor epidermal growth factor receptor expression had poorer disease-specific survival than subjects in other groups. Studies assessing the impact of smoking on cancer treatment effectiveness are listed in Table 2.

Correlation Between Continued Smoking and Second Primary Tumors. Multiple studies have found that subjects who continued smoking after cancer diagnosis had an increased risk of developing a second primary malignancy (see Table 2). ${ }^{28}$ Kinoshita et $\mathrm{al}^{21}$ examined the risk of a second primary tumor in subjects with gastric cancer in relation to adjuvant immunochemotherapy after curative resection and smoking and drinking habits. Among 1,614 gastric cancer subjects, 149 developed a second primary tumor during the period from 1978 to 1995 .

This study did not show a significantly increased risk for second primary tumors after adjuvant therapy for gastric cancer. An increased risk for second primaries in current smokers and ex-daily drinkers was observed in this study. The hazard ratio regarding the association between smoking habit and the risk for second primaries for males was $1.82(1.02-3.26)$ for current smokers and $0.95(0.42$ 2.13) for ex-smokers compared with the risk in those who had never smoked and after adjusting for age, stage, type of adjuvant therapy, and drinking habit. Even more striking results were obtained when the association between smoking habits and second primaries was re-evaluated in terms of smoking-related cancers, involving second primary malignancies restricted to esophageal, laryngeal, lung, and bladder cancer. In these cases, the hazard ratio regarding the relation between smoking status and second primaries increased to 3.00 (range of 1.24-7.28) for current smokers and 1.04 (range of 0.32-3.39) for ex-smokers compared with never smokers. No excess risk was found in ex-smokers, which could be strong motivation for smokers with gastric cancer to quit smoking.

The risk of a second primary in relation to smoking and treatment in long-term survivors with small-cell lung cancer was also evaluated by Tucker et al. ${ }^{22}$ Six-hundred eleven subjects with small-cell lung cancer who survived cancerfree for $\geq 2 \mathrm{y}$ were included in the analysis. Most of the survivors had limited-stage disease, and the average follow-up period was $5.2 \mathrm{y}$. A total of 103 second primary cancers were identified. Overall, the risk of any second cancer was increased by 3.5 -fold in this group of subjects. Smoking-related cancers (lung, head and neck, laryngeal, bladder, esophageal, stomach, pancreatic, and kidney) were disproportionately represented with a 7 -fold increase (95\% CI 5.2-8.7). Cancers not related to smoking were not significantly increased (observed/expected $=1.5$, 95\% CI $0.98-2.2$ ).

Most of the increased risk was attributed to 51 second lung cancers with a histological type other than small cell. ${ }^{22}$ The cumulative risk of a second lung cancer was $32 \% \pm 5 \%$ at $12 \mathrm{y}$ and did not appear to reach a plateau. Subjects irradiated in the chest had a 13 -fold increased risk of developing a second lung cancer compared with a 6-fold increased risk among those who were not irradiated.

The risk of a second lung cancer varied with smoking status, with no second lung cancers occurring in the small number of subjects who were non-smokers. ${ }^{22}$ In those who stopped smoking before the diagnosis of small-cell lung cancer (mean pack-years of $46 \pm 28$ ), the risk was stable over time. In those who stopped at the time of diagnosis 
(mean pack-years of $53 \pm 24$ ), the risk increased over time $(P=.009)$. The highest risk was found among those who continued to smoke after small-cell lung cancer diagnosis (mean packs-years of $53 \pm 24$ ). The risk of a second lung cancer did not vary significantly by pack-years at the time of small-cell lung cancer diagnosis.

The authors also evaluated the combined effects of smoking status and radiation therapy. ${ }^{22}$ Among those who stopped smoking, the risks were similar in those who did and did not receive radiation therapy. Trends over time were similar and not significant for either group. Among those who continued to smoke, the risks were much higher among those treated with chest irradiation and increased significantly over time. The interaction between smoking and chest irradiation was substantial but not statistically significant because of the relatively small number of events. Subjects treated with various forms of combination chemotherapy showed comparable increases in the risk of a second primary tumor (9.4-13-fold overall), except for those who continued to smoke and were treated with alkylating agents, who showed a 19 -fold increased risk.

This study clearly demonstrated that continued smoking increased the risk of a second lung cancer in subjects who had been treated for small-cell lung carcinoma. ${ }^{22}$ In those who continued to smoke, the risk was approximately double overall. The increase in risk among persistent smokers could not be explained by the increment in accumulated pack-years. Although the risk was also increased for laryngeal and other smoking-related cancers, it seems that the entire aerodigestive epithelium is at risk. This study also suggests that there is probably a synergism between chest irradiation and smoking in the development of second lung cancers. Smoking may act as a promoter in tissues with radiation-induced genomic instability.

In conclusion, this study demonstrated that the effects of both radiation therapy and chemotherapy on the development of second primary cancers were substantially enhanced in subjects who continued to smoke. ${ }^{22}$ The risk of a second cancer was much lower in those who quit smoking.

\section{Clinical Importance of Smoking Cessation on Quality of Life, Pain, and Performance Status}

In this section of our review, we evaluated 6 studies. Three were performed in lung cancer subjects and assessed quality of life and performance status. Different questionnaires for the assessment of quality of life were used; therefore, any comparison between the results was difficult. One study of quality of life was performed in subjects with head and neck cancer. We also reviewed 2 studies in which pain, a major component of quality of life, was assessed in relation to smoking status.
Garces et $\mathrm{al}^{29}$ evaluated whether smoking cessation after lung cancer diagnosis improves quality of life in lung cancer subjects. Cigarette-smoking patterns at the time of lung cancer diagnosis and at follow-up were assessed to determine the impact of cigarette smoking on a subject's quality of life as measured by the Lung Cancer Symptom Scale (LCSS). The LCSS consists of 9 individual items, and the total score is the average of the sum of those 9 individual items. The first 6 items represent measures of the specified lung cancer symptoms, including appetite, fatigue, cough, shortness of breath, hemoptysis, and pain. The remaining 3 items measure general lung cancer symptoms and how the illness affects normal activities and overall quality of life. The items are ranked on a visual analog scale of $0-100 \mathrm{~mm}$.

A total of 1,028 subjects with non-small-cell lung cancer and small-cell lung cancer entered the study. ${ }^{29}$ Smokers were classified as never-smokers, ex-smokers, or current smokers. The total number of packs/d and total number of pack-years of the smoking history were recorded. The adjusted mean \pm SD total LCSS for never-smokers and persistent smokers were $17.6 \pm 4.02$ and $28.7 \pm 5.09$, respectively $(P<.001)$, whereas ex-smokers (abstinent and relapsed) had adjusted mean \pm SD total LCSS scores that were similar to those of never-smokers (ex-smokers, $19.8 \pm 4.12$; never-smokers, $20.0 \pm 4.9$ ). The lower quality-of-life scores corresponded to a better quality of life among never-smokers compared with persistent smokers, who had the highest scores and the worst quality of life.

Similar trends and findings regarding total LCSS were noted for all 9 individual LCSS items among different categories of never-smokers, ex-smokers, persistent smokers, and abstinent smokers. ${ }^{29}$ The results regarding 7 of the 9 individual items were clinically and statistically significant. This means that persistent smokers had worse appetite, fatigue, cough, shortness of breath, symptomatic distress, effect on activities, and overall quality of life compared with never-smokers, with ex-smokers and abstinent smokers having intermediate adjusted LCSS. No dose-response difference was found between the number of packs/d or the total number of subjects and the adjusted LCSS, but this finding was limited by the small number of subjects in each category of cigarette consumption.

The quality of life in subjects with head and neck cancer has been investigated by Gritz et al. ${ }^{30}$ In this study, at baseline, subjects were current smokers or had quit within the previous 12 months. Subjects who were ex-smokers after $1 \mathrm{y}$ of follow-up reported higher quality-of-life scores than subjects who had not stopped smoking.

Quality of life in relation to smoking status was evaluated after lung cancer surgery by Balduyck et al. ${ }^{31}$ In this 
study, 70 subjects with non-small-cell lung cancer underwent lobectomy or pneumonectomy. Quality of life was prospectively recorded at baseline (1 $\mathrm{d}$ before surgery) and at $1,3,6$, and 12 months postoperatively using the European Organisation for Research and Treatment of Cancer quality-of-life questionnaires QLQ-C30 and QLQ-LC13 (lung cancer-specific). ${ }^{32,33}$ Baseline quality-of-life scores were comparable in the 4 subgroups of the study (nonsmokers, ex-smokers, recent ex-smokers, current smokers). Non-smokers showed the best postoperative qualityof-life evolution. All quality-of-life domains returned to baseline in the first month after surgery with the exception of physical functioning. Ex-smokers returned to baseline in most quality-of-life domains 1 month after surgery, although they reported functional deficits during the first 3 months, persistent decreases in role functioning at 12 months, and temporary increases in general and thoracic pain the first month. Compared with the previous subgroups, recent ex-smokers reported longer physical functioning impairment up to 6 months after surgery and an increase in dyspnea at 1 and 3 months postoperatively. Current smokers reported a persistent decrease in physical and social functional status during the entire follow-up period, as well as general and thoracic pain up to 12 months after surgery.

The effect of post-diagnosis smoking cessation on performance status was evaluated in the study of Baser et al ${ }^{34}$ in a population of subjects with non-small-cell lung cancer. Participants were classified as current smokers, neversmokers, and ex-smokers, and performance status was classified according to the criteria of the Eastern Cooperative Oncology Group. Overall survival was assessed in this study, and performance change at 0,6 , and 12 months was calculated.

A total of 206 subjects with non-small-cell lung cancer were included in the study and received surgical, medical, or combined surgical/medical therapy. ${ }^{34}$ Forty-five percent were current smokers, $48 \%$ were ex-smokers, and $7 \%$ never-smokers. Subjects who had quit smoking maintained a better performance status at $0-6$ months (odds ratio of $7.09, P=.002$ ) and at $0-12$ months (odds ratio of 6.99 , $P=.006$ ) than those who continued to smoke regardless of disease stage, age, race, sex, cancer-related treatment modality (surgical vs medical treatment), and comorbidities. In this study, survival differences between the 2 groups of subjects were not statistically significant, possibly due to the small number of subjects.

According to the authors, several factors may contribute to performance status deterioration, including airway inflammation, decreased lung function, and reduced mucociliary clearance due to the irritant effect of cigarette smoke, as well as tobacco-induced COPD exacerbations. ${ }^{34}$ Several biological mechanisms could also explain performance status deterioration, such as increased levels of carbon monoxide in active smokers and the subsequent tissue hypoxia associated with suboptimal outcomes following chemotherapy or radiation treatment.

Pain in cancer patients is of particular interest, as 30$45 \%$ of cancer subjects with early-stage disease experience moderate-to-severe pain, and nearly $75 \%$ with advanced-stage disease report moderate-to-very severe pain. There is also emerging evidence of a unique relationship between recurrent pain and tobacco use in the general population. Smoking has been associated with the occurrence and aggravation of several conditions associated with chronic pain. ${ }^{35}$

Daniel et $\mathrm{al}^{36}$ tested the cross-sectional association between post-diagnosis smoking status and pain ratings among lung cancer subjects and found that current smokers reported greater pain (odds ratio of $1.6,95 \%$ CI 1.12.4 ) than a group composed of both ex-smokers and neversmokers.

Ditre et a ${ }^{37}$ examined smoking status and pain reporting in greater detail across a wider range of cancer subjects along with the potential benefits of smoking cessation. Participants in this study were subjects with cancer scheduled to receive out-patient cytotoxic chemotherapy over a period of at least 9 weeks and having an Eastern Cooperative Oncology Group performance status of $\leq 2$. Smoking status and cigarette consumption were determined via self-report at baseline assessment. Subjects were classified as never-smokers, ex-smokers, or current smokers. Pain status and pain interference were assessed using the Medical Outcomes Survey 36-Item Short Form, which is a widely used self-report measure of physical and mental well-being. Pain-related distress was measured using the Memorial Symptom Assessment Scale Short Form, which is a self-report measure of the severity of 32 symptoms commonly experienced by cancer patients. A total of 224 subjects participated in the study. Cancer diagnoses were categorized as breast cancer $(34.82 \%)$, lung cancer (33.04\%), and other cancer types (32.14\%).

Current smokers reported experiencing more severe pain than never-smokers $(P<.01)$, whereas there were no difference in the severity of pain between ex-smokers and current smokers or never-smokers. ${ }^{37}$ Analysis also revealed significant differences in self-reported pain-related interference with daily routine across study groups. Current smokers reported having experienced greater interference from pain than never-smokers $(P<.01)$ and ex-smokers $(P<.01)$. No differences in pain-related interference were observed between ex-smokers and never-smokers. There were no differences in the degree to which subjects experienced distress associated with pain in relation to smoking status.

A significant negative correlation between self-reported pain severity and the number of years since quitting smoking in ex-smokers was revealed $(P<.01) .{ }^{37} \mathrm{~A}$ similar 


\section{Smoking Cessation in Subjects With Cancer}

Table 3. Studies Regarding the Impact of Smoking on Quality of Life and Pain in Cancer Subjects

\begin{tabular}{|c|c|c|c|c|c|c|}
\hline Reference & $\begin{array}{c}\text { Type of } \\
\text { Cancer/Stage }\end{array}$ & $\begin{array}{l}\text { Subjects } \\
\quad(n)\end{array}$ & $\begin{array}{l}\text { Study } \\
\text { Design }\end{array}$ & $\begin{array}{l}\text { Assessment of } \\
\text { Smoking Status }\end{array}$ & Outcomes & $\begin{array}{c}\text { Main Results in Relation to } \\
\text { Smoking Status }\end{array}$ \\
\hline Garces et $\mathrm{al}^{29}$ & $\begin{array}{l}\text { Small-cell and non- } \\
\text { small-cell lung } \\
\text { cancer }\end{array}$ & 1,028 & Prospective & $\begin{array}{l}\text { Never-smokers, ex- } \\
\text { smokers, current } \\
\text { smokers }\end{array}$ & Quality of life (LCSS) & $\begin{array}{l}\text { Worst quality of life in current } \\
\text { smokers ( } 7 \text { of } 9 \text { items in } \\
\text { LCSS) }\end{array}$ \\
\hline Gritz et al ${ }^{30}$ & Head and neck & 105 & Prospective & $\begin{array}{l}\text { Current smokers, ex- } \\
\text { smokers (baseline) } \\
\text { Current/ex-smokers } \\
\text { (follow-up) }\end{array}$ & $\begin{array}{l}\text { Quality of life (KPS, } \\
\text { CARES-SF, PSS- } \\
\text { HN, POMS) }\end{array}$ & $\begin{array}{l}\text { Improved quality of life in } \\
\text { ex-smokers }\end{array}$ \\
\hline Balduyck et al ${ }^{31}$ & $\begin{array}{l}\text { Non-small-cell lung } \\
\text { cancer (early } \\
\text { stage after lung } \\
\text { cancer surgery) }\end{array}$ & 70 & Prospective & $\begin{array}{l}\text { Non-smokers, ex-smokers, } \\
\text { recent ex-smokers, } \\
\text { current smokers }\end{array}$ & $\begin{array}{l}\text { Quality of life } \\
\text { (EORTC QLQ-C30 } \\
\text { and QLQ-LC13) }\end{array}$ & $\begin{array}{l}\text { Poorer postoperative quality of } \\
\text { life in current smokers }\end{array}$ \\
\hline Baser et al ${ }^{34}$ & $\begin{array}{l}\text { Non-small-cell lung } \\
\text { cancer (stages } \\
\text { I-IV) }\end{array}$ & 206 & Retrospective & $\begin{array}{l}\text { Never-smokers, ex- } \\
\text { smokers, current } \\
\text { smokers }\end{array}$ & $\begin{array}{l}\text { Performance status } \\
\quad \text { (ECOG criteria) } \\
\text { Survival }\end{array}$ & $\begin{array}{l}\text { Better performance status in } \\
\text { ex-smokers } \\
\text { No impact on survival }\end{array}$ \\
\hline Daniel et $\mathrm{al}^{36}$ & Lung cancer & 893 & Prospective & $\begin{array}{l}\text { Non-smokers, ex-smokers, } \\
\text { persistent smokers }\end{array}$ & Pain level (scale 0-10) & $\begin{array}{l}\text { Higher reported levels of usual } \\
\text { pain in persistent smokers }\end{array}$ \\
\hline \multirow[t]{3}{*}{ Ditre et $\mathrm{al}^{37}$} & $\begin{array}{l}\text { Lung cancer, breast } \\
\text { cancer, other } \\
\text { types of cancer }\end{array}$ & 224 & Prospective & $\begin{array}{l}\text { Never-smokers, ex- } \\
\text { smokers, current } \\
\text { smokers }\end{array}$ & Pain status & $\begin{array}{l}\text { More severe pain in current } \\
\text { smokers, no differences in } \\
\text { never-smokers and ex- } \\
\text { smokers }\end{array}$ \\
\hline & & & & & Pain interference & $\begin{array}{l}\text { Greater interference from pain } \\
\text { in current smokers }\end{array}$ \\
\hline & & & & & $\begin{array}{l}\text { Pain-related distress } \\
\text { (SF-36 and MSAS- } \\
\text { SF scales) }\end{array}$ & \\
\hline
\end{tabular}

LCSS $=$ Lung Cancer Symptom Scale

KPS $=$ Karnofsky Performance Scale

CARES-SF $=$ Cancer Rehabilitation Evaluation System Short Form

PSS-HN $=$ Performance Status Scale for Head \& Neck Cancer Patients

POMS $=$ Profile Of Mood States

EORTC $=$ European Organisation for Research and Treatment of Cancer

QLQ-C30 = quality-of-life questionnaire

QLQ-LC13 = quality-of-life questionnaire lung cancer-specific

ECOG $=$ Eastern Cooperative Oncology Group

SF-36 $=$ Medical Outcomes Survey 36-Item Short Form

MSAS-SF $=$ Memorial Symptom Assessment Scale Short Form

inverse relation was observed between self-reported painassociated impairment and the number of years since quitting $(P<.01)$. There was no significant correlation between pain-related distress and years since quitting.

In both current smokers and ex-smokers, analysis revealed no significant correlations between the number of cigarettes smoked per day and pain severity, pain interference, or pain-related stress. ${ }^{37}$ Finally, the authors concluded that continued smoking despite cancer diagnosis was associated with increased pain and increased pain-associated functional impairment after adjusting for age, gender, surgery status, disease stage, and education, and a negative correlation between pain rating and the number of years since quitting smoking was also observed.

The characteristics of the participants in studies included in this review, measured outcomes, and main results in relation to smoking are presented in Table 3 .

\section{Discussion}

In this review, we evaluated 20 studies regarding smoking and smoking cessation in cancer subjects in relation to 4 different topics: survival/mortality or disease progression, impact on anti-cancer treatment, risk of second primary malignancies, and quality of life. Most studies were performed in subjects with smoking-related cancers, such as lung, bladder, and head and neck cancer. A common limitation of these studies is that smoking status was not biochemically evaluated, so there may be a potential bias. Many of the studies were observational, with small or moderate sample sizes. Regarding smoking status, there were no unanimous definitions of ex-smokers and recent or distant ex-smokers. Some studies used a period of $10 \mathrm{y}$ from smoking cessation as a criterion for the categorization of subjects into distant and recent ex-smokers, ${ }^{12,13}$ 
whereas other researchers classified subjects into $>2$ groups based on the duration of abstinence: 1-8, 9-17, and $\geq 18 \mathrm{y}^{9}$ or $<1,1-4,5-9$, and $\geq 10 \mathrm{y}^{38}$ from smoking cessation.

In 3 studies, the impact of smoking on survival in subjects with limited-stage small-cell lung cancer ${ }^{8,15}$ and early-stage non-small-cell lung cancer ${ }^{9,15}$ was evaluated. None of these studies assessed lung cancer-specific survival. The results of 2 studies in limited-stage small-cell lung cancer subjects were conflicting, although even in a study that failed to demonstrate statistically significant improvement on overall survival, subjects who quit smoking experienced a survival benefit. ${ }^{10}$ This is very important in a detrimental disease such as small-cell lung cancer. The most important finding in the study involving early-stage non-small-cell lung cancer subjects ${ }^{9}$ is the stronger beneficial effect of smoking cessation on overall survival and recurrence-free survival in light smokers compared with heavy smokers and in women. The results of a study in subjects with oral cancer ${ }^{11}$ are important, but limited by the small sample size.

The results of studies ${ }^{12,13}$ involving subjects with nonmuscle-invasive bladder cancer with end points of diseasefree survival, progression, and overall survival are very interesting. Although cigarette smoking is considered an established risk factor for the development of bladder cancer, ${ }^{38}$ there has been no strong evidence on the effects of smoking on bladder cancer prognosis until recently. ${ }^{39}$ The studies were well designed, with a large number of subjects and detailed recording of smoking status, including intensity and duration of smoking. Long-term heavy smokers with primary or recurrent urinary bladder cancer had the worst outcomes, a finding that emphasizes the necessity for smoking cessation counseling in urological patients.

A study on women with breast cancer ${ }^{16}$ reported some important results, but the most striking finding was that smoking affects not only overall mortality but also breast cancer-specific mortality, although this conclusion derived from a small proportion of current smokers. Evaluation of the dose-response relationship between smoking and outcome was limited by the lack of detailed information about cigarette consumption and smoking status during the follow-up period.

The effect of continued smoking or cessation on anticancer treatment effectiveness is of major importance. The results of the randomized study by Browman et $\mathrm{al}^{16}$ in subjects with locally advanced head and neck cancer showing a better survival in ex-smokers are extremely important, and this study remains a hallmark, although $>15 \mathrm{y}$ have passed since its publication. The same authors in a more recent study failed to prove a statistically significant difference in survival, although abstainers and very light smokers had better survival rates than light, moderate, and heavy smokers. ${ }^{40}$ This observational study also demonstrated that baseline smoking status was an independent predictor of survival.

Differences in survival rates with regard to smoking status in subjects with advanced non-small-cell lung cancer under treatment with erlotinib were demonstrated in large randomized clinical trials and are now clear and well-described. ${ }^{17-19,25-27}$ Every candidate for treatment with erlotinib should be strongly advised to quit smoking to achieve a higher survival rate.

In addition to the results from clinical trials, recent evidence in animal models suggests that nicotine induces resistance to cancer therapy by inhibiting apoptosis in lung cancer cells. ${ }^{41}$ The researchers designed a study using a combination of 2 chemotherapeutic agents to assess the anti-apoptotic effects of nicotine in A549 cells (cells generated from mitochondrial DNA). These cells were processed with nicotine for $24 \mathrm{~h}$, followed by cisplatin, etoposide, or both. Nicotine significantly reduced both cisplatin-induced and etoposide-induced apoptosis by modulating the signaling pathway. These effects of nicotine are critically important especially in patients undergoing treatment for lung cancer because activation of the mitochondrial death pathway is one of the most common mechanisms by which many anti-cancer therapeutic agents induce apoptosis in tumor cells. These findings demonstrate that both active smoking and nicotine supplementation may compromise the response of cancer patients to chemotherapy. Another study in which the authors used an in vitro model to mimic long-term smoking in human lung cancer concluded that lung cancer cells with long-term exposure to cigarette smoke condensates become much more resistant to carboplatin chemotherapy. ${ }^{42}$ Confirming these results in humans is an issue that remains to be addressed.

The risk of a second primary malignancy is increasing as the number of cancer survivors increases. ${ }^{43}$ Kinoshita et $\mathrm{al}^{21}$ observed that subjects with gastric cancer who continued to smoke had a 3-fold risk of developing a second smoking-related malignancy. Also, subjects who survived small-cell lung cancer for $>2 \mathrm{y}$ and continued to smoke had a 7-fold increased risk for a second smoking-related malignancy. ${ }^{22}$ These findings come from a well-designed study in a moderate number of subjects. Although this study also indicates that the treatment of small-cell lung cancer (chemoradiotherapy) may affect the risk of a second primary lung cancer, this risk seems to be much lower in patients who quit smoking.

The last topic addressed in this review is the effect of smoking on quality of life in cancer patients. A common issue in these studies is the different questionnaires used for the assessment of quality of life, complicating the comparison between different studies. Gritz et $\mathrm{al}^{30}$ assessed 
quality of life in subjects with lung cancer (both small and non-small cell) using the LCSS as described above. The results suggest that persistent smoking after a lung cancer diagnosis reduces quality of life. Despite its limitations, such as selection and survival biases, the results of this study are important and underline the need for smoking cessation interventions after lung cancer diagnosis.

Balduyck et $\mathrm{al}^{31}$ investigated the effect of smoking on quality of life after surgery for early-stage non-small-cell lung cancer. The authors concluded that smoking cessation is beneficial at any time relative to lung cancer surgery and that subjects who continued to smoke experience a poorer postoperative quality of life. The results of this study add to the information coming from previously published studies showing that smokers who quit $>10$ weeks before surgery have a similar risk for postoperative pulmonary complications as never-smokers. ${ }^{44}$ There are some limitations regarding the small number of patients included and the use of the QLQ-C30 and QLQ-LC13 questionnaires for the assessment of quality of life, which are validated only for subjects with advanced disease (stages III and IV).

Pain is a major problem that reduces quality of life in patients with cancer. Data indicate that continued smoking in patients with cancer is associated with increased pain and greater pain-associated functional deterioration. ${ }^{37}$ These results come from studies involving subjects with a range of different cancer diagnoses and show even distribution across disease stages I-IV. Important limitations of this study are the lack of information about the mechanisms underlying the association between pain and current smoking and the use of cross-sectional data that do not allow the establishment of causal relationships. Despite these limitations, as cancer patients tend to smoke for self-medication, such conclusions could be used to motivate them to quit smoking. Further studies are needed to obtain more clear results on the association between smoking and pain, which could be used in every patient with cancer.

An issue related to quality of life in cancer patients is the effect of smoking on performance status, which has been investigated in non-small-cell lung cancer patients by Bergman et al. ${ }^{33}$ This study suggested that subjects who quit smoking after the diagnosis of lung cancer maintained a better performance status over time, although differences in survival according to smoking status were not found. This study adds to the existing knowledge that smoking cessation after the diagnosis of lung cancer has a beneficial effect on performance status.

In conclusion, the importance of smoking cessation for all cancer patients, especially those with smoking-related tumors, has been clearly demonstrated in the present review. Although cancer diagnosis and treatment may be teachable moments for smoking cessation, these opportu- nities may be underestimated by health-care professionals, as most smoking cessation efforts focus on primary prevention. Health-care providers and patients would benefit from learning about the adverse effects of continued smoking on cancer survival rates, treatment effectiveness, risk for second primary malignancies, and quality of life. Patients who continue to smoke after cancer diagnosis or treatment should be identified, and smoking cessation interventions for this specific group of smokers and their families should be available and implemented.

\section{REFERENCES}

1. Oppeltz RF, Jatoi I. Tobacco and the escalating global cancer burden. J Oncol 2011;2011:408104.

2. Zon RT, Goss E, Vogel VG, Chlebowski RT, Jatoi I, Robson ME, et al. American Society of Clinical Oncology Policy Statement: the role of the oncologist in cancer prevention and risk assessment. J Clin Oncol 2009;27(6):986-993.

3. Gritz ER, Fingeret MC, Vidrine DJ, Lazev AB, Mehta NV, Reece GP. Successes and failures of the teachable moment: smoking cessation in cancer patients. Cancer 2006;106(1):17-27.

4. Nayan SN, Gupta MK, Sommer DD. Evaluating smoking cessation interventions and cessation rates in cancer patients: a systematic review and meta-analysis. ISRN Oncol 2011;2011:849023.

5. Wieseler B, McGauran N. Reporting a systematic review. Chest 2010;137(5):1240-1246.

6. Johnston-Early A, Cohen MH, Minna JD, Paxton LM, Fossieck BE Jr, Ihde DC, et al. Smoking abstinence and small cell lung cancer survival: an association. JAMA 1980;244(19):2175-2179.

7. Bergman B, Sörenson S. Smoking and effect of chemotherapy in small cell lung cancer. Eur Respir J 1988;1(10):932-937.

8. Videtic GM, Stitt LW, Dar AR, Kocha WI, Tomiak AT, Truong PT, et al. Continued cigarette smoking by patients receiving concurrent chemo-radiotherapy for limited-stage small cell lung cancer is associated with decreased survival. J Clin Oncol 2003;21(8):1544-1549.

9. Zhou W, Heist RS, Liu G, Park S, Neuberg DS, Asomaning K, et al. Smoking cessation before diagnosis and survival in early stage nonsmall cell lung cancer patients. Lung Cancer 2006;53(3):375-380.

10. Chen J, Jiang R, Garces YI, Jatoi A, Stoddard SM, Sun Z, et al. Prognostic factors for limited stage SCLC: a study of 284 patients. Lung Cancer 2010;67(2):221-226.

11. Jerjes W, Upile T, Randi H, Petrie A, Abiola J, Adams A, et al. The effect of tobacco and alcohol and their reduction/cessation on mortality in oral cancer patients: short communication. Head Neck Oncol 2012;4:6.

12. Rink M, Furberg H, Zabor EC, Xylinas E, Babjuk M, Pycha A, et al. Impact of smoking and smoking cessation on oncologic outcomes in primary nonmuscle-invasive bladder cancer. Eur Urol 2013;63(4): 724-732.

13. Rink M, Xylinas E, Babjuk M, Hansen J, Pycha A, Comploj E, et al. Impact of smoking on outcomes of patients with a history of recurrent nonmuscle invasive bladder cancer. J Urol 2012;188(6):21202127.

14. Braithwaite D, Izano M, Moore DH, Kwan ML, Tammemagi MC, Hiatt RA, et al. Smoking and survival after breast cancer diagnosis: a prospective observational study and systematic review. Breast Cancer Res Treat 2012;136(2):521-533.

15. Saito-Nakaya K, Nakaya N, Fujimori M, Akizuki N, Yoshikawa E, Kobayakawa M, et al. Marital status, social support and survival after curative resection in non-small-cell lung cancer. Cancer Sci 2006;97(3):206-213. 


\section{Smoking Cessation in Subjects With Cancer}

16. Browman GP, Wong G, Hodson I, Sathya J, Russell R, McAlpine L, et al. Influence of cigarette smoking on the efficacy of radiation therapy in head and neck cancer. N Engl J Med 1993;328(3):159-163.

17. Clark GM, Zborowski DM, Santabarbara P, Ding K, Whitehead M, Seymour L, Shepherd FA. Smoking history and epidermal growth factor receptor expression as predictors of survival benefit from erlotinib for patients with non-small cell lung cancer in the national cancer institute of Canada clinical trials group study BR. Clin Lung Cancer 2006;7(6):389-394.

18. Shepherd FA, Rodrigues Pereira J, Ciuleanu T, Tan EH, Hirsh V, Thongprasert S, et al. Erlotinib in previously treated non-small cell lung cancer. N Engl J Med 2005;353(2):123-132.

19. Johnson JR, Cohen M, Sridhara R, Chen YF, Williams GM, Duan J, et al. Approval summary for erlotinib for treatment of patients with locally advanced or metastatic non-small cell lung cancer after failure of at least one prior chemotherapy regimen. Clin Cancer Res 2005;11(18):6414-6421.

20. Kumar B, Cordell KG, Lee JS, Worden FP, Prince ME, Tran HH, et al. EGFR, p16, HPV titer, Bcl-xL and p53, sex, and smoking as indicators of response to therapy and survival in oropharyngeal cancer. J Clin Oncol 2008;26(19):3128-3137.

21. Kinoshita Y, Tsukuma H, Ajiki W, Kinoshita N, Oshima A, Hiratsuka M, Furukawa $\mathrm{H}$. The risk of second primaries in gastric cancer patients: adjuvant therapy and habitual smoking and drinking. J Epidemiol 2000;10(5):300-304.

22. Tucker MA, Murray N, Shaw EG, Ettinger DS, Mabry M, Huber $\mathrm{MH}$, et al. Second primary cancers related to smoking and treatment of small-cell lung cancer. J Natl Cancer Inst 1997;89(23):1782-1788.

23. Heusch WL, Maneckjee R. Signaling pathways involved in nicotine regulation of apoptosis of human lung cancer cells. Carcinogenesis 1998;19(4):551-556.

24. Heeschen C, Jang JJ, Weis M, Pathak A, Kaji S, Hu RS, et al. Nicotine stimulates angiogenesis and promotes tumor growth and atherosclerosis. Nat Med 2001;7(7):833-839.

25. Huang $\mathrm{CH}$, Powers $\mathrm{BC}$. The evolving role of maintenance therapy using epidermal growth factor receptor tyrosine kinase inhibitors in the management of advanced non-small-cell lung cancer. Clin Med Insights Oncol 2012;6:137-147.

26. Hughes AN, O'Brien ME, Petty WJ, Chick JB, Rankin E, Woll PJ, et al. Overcoming CYPA1/1A2 mediated induction metabolism by escalating erlotinib dose in current smokers. J Clin Oncol 2009; 27(8):1220-1226.

27. Hamilton M, Wolf JL, Rusk J, Beard SE, Clark GM, Witt K, Cagnoni PJ. Effects of smoking on the pharmacokinetics of erlotinib. Clin Cancer Res 2006;12(7 Pt 1):2166-2171.

28. Richardson GE, Tucker MA, Venzon DJ, Linnoila RI, Phelps R, Phares JC, et al. Smoking cessation after successful treatment of small-cell lung cancer is associated with fewer smoking-related second primary cancers. Ann Intern Med 1993;119(5):383-390.

29. Garces YI, Yang P, Parkinson J, Zhao X, Wampfler JA, Ebbert JO, Sloan JA. The relationship between cigarette smoking and quality of life after lung cancer diagnosis. Chest 2004;126(6):1733-1741.
30. Gritz ER, Carmack CL, de Moor C, Coscarelli A, Schacherer CW, Meyers EG, Abemayor E. First year after head and neck cancer: quality of life. J Clin Oncol 1999;17(1):352-360.

31. Balduyck B, Sardari Nia P, Cogen A, Dockx Y, Lauwers P, Hendriks J, Van Schil P. The effect of smoking cessation on quality of life after lung cancer surgery. Eur J Cardiothorac Surg 2011;40(6):14321437; discussion 1437-1438.

32. Aaronson NK, Ahmedzai S, Bergman B, Bullinger M, Cull A, Duez NJ, et al. The European Organization for Research and Treatment of Cancer QLQ C30: a quality of life instrument for use in international clinical trials in oncology. J Natl Cancer Inst 1993;85(5):365-376.

33. Bergman B, Aaronson NK, Ahmedzai S, Kaasa S, Sullivan M. The EORTC QLQ-LC13: a modular supplement to the EORTC Core Quality of Life Questionnaire (QLQ-C30) for use in lung cancer clinical trials. EORTC Study Group on Quality of Life. Eur J Cancer 1994:30A(5):635-642.

34. Baser S, Shannon VR, Eapen GA, Jimenez CA, Onn A, Lin E, Morice RC. Smoking cessation after diagnosis of lung cancer is associated with a beneficial effect on performance status. Chest 2006; 130(6):1784-1790.

35. Ditre JW, Brandon TH. Pain as a motivator of smoking: effects of pain induction on smoking urge and behavior. J Abnorm Psychol 2008;117(2):467-472.

36. Daniel M, Keefe FJ, Lyna P, Peterson B, Garst J, Kelley M, et al. Persistent smoking after the diagnosis of lung cancer is associated with higher reported pain levels. J Pain 2009;10(3):323-328.

37. Ditre JW, Gonzalez BD, Simmons VN, Faul LA, Brandon TH, Jacobsen PB. Associations between pain and current smoking status among cancer patients. Pain 2011;152(1):60-65.

38. Freedman ND, Silverman DT, Hollenbeck AR, Schatzkin A, Abnet CC. Association between smoking and risk of bladder cancer among men and women. JAMA 2011;306(7):737-745.

39. Aveyard P, Adab P, Cheng KK, Wallace DM, Hey K, Murphy MF. Does smoking status influence the prognosis of bladder cancer? A systematic review. BJU Int 2002;90(3):228-239.

40. Browman GP, Mohide EA, Willan A, Hodson I, Wong G, Grimard $\mathrm{L}$, et al. Association between smoking during radiotherapy and prognosis in head and neck cancer: a follow-up study. Head Neck 2002; 24(12):1031-1037.

41. Zhang J, Kamdar O, Le W, Rosen GD, Upadhyay D. Nicotine induces resistance to chemotherapy by modulating mitochondrial signaling in lung cancer. Am J Respir Cell Mol Biol 2009;40(2):135146.

42. Samanta D, Kaufman J, Carbone DP, Datta PK. Long-term smoking mediated down-regulation of Smad3 induces resistance to carboplatin in non-small cell lung cancer. Neoplasia 2012;14(7):644-655.

43. Mayer DK, Carlson J. Smoking patterns in cancer survivors. Nicotine Tob Res 2011;13(1):34-40.

44. Nakagawa M, Tanaka H, Tsukuma H, Kishi Y. Relationship between the duration of preoperative smoke-free period and the incidence of postoperative pulmonary complications after pulmonary surgery. Chest 2001;120(3):705-710 